УДК 001.895:[338.28:004.67:330.341]

DOI: https://doi.org/10.37320/2415-3583/17.6

Горященко Ю.Г.

кандидат економічних наук, доцент Університет митної справи та фінансів ORCID: https://orcid.org/0000-0001-7020-1412

\title{
УПРАВЛІННЯ ІННОВАЦІЙНИМ РОЗВИТКОМ ПІДПРИЕМСТВ В УМОВАХ ЦИФРОВІЗАЦІї
}

У статті розглянуто процеси планування, організації, мотивації і контролю інноваційного розвитку на підприємстві, які в сукупності формують його систему управління. Підкреслено необхідність залучення підприємств у систему стратегічного управління інноваційним розвитком для створення конкурентних переваг, таких як розширення ринку, оптимізаџія витрат, вихід на зовнішні ринки, зростання доходів тощь. Наголошено на необхідності створення на підприємствах окремих иентрів компетенцій з інновацій та цฺифрових технологій (загальнокорпоративних иееттів інновацій, центру інновацій ритейлу), а також залучення до штату інноваиійних менеджерів. Доведено перевагу інноваџійних підходів до мотиваџії персоналу підприємств над традииійними. Запропоновано проведення анкетування для визначення стану і рівня професійної мотивації працівників підприємств із метою підтримки інновачійного розвитку.

Ключові слова: інноваційний розвиток підприємств, циифровізація, управління, філософія інноваційного підприємництва, бізнес, організація.

Постановка проблеми. Філософія інноваційного підприємництва полягає у спробі знайти відповіді на основні бізнесові питання за допомогою міркування, інтелекту, знань, мудрості з метою орієнтації основних акторів інноваційного розвитку у розбудові інноваційної екосистеми країни та світу. Така особлива форма пізнання особливостей підприємництва притаманна керівникам бізнесових структур, які найкраще розуміють загальні суттєві характеристики і фундаментальні принципи бізнесу та здатні приймати

відповідні управлінські рішення у швидко змінюваних умовах.

Аналіз останніх досліджень і публікацій. Проблеми управління інноваційним розвитком досліджували вчені Р. Акофф, С.А. Бондаренко, В.М. Геєць, П.Л. Гринько, А.П. Грінько, К. Друрі, С.М. Ілляшенко, Р. Калман, Л.І. Федулова, М.В. Чорна та ін. Питаннями розбудови інноваційної екосистеми та інноваційного простору займалися Ю.Н. Андросик, I.К. Бистряков, М.I. Богдан, А. Брамвелл, О.А. Довгаль, 
Г.В. Довгаль, 3.О. Коваль, О.Г. Коломієць, Н.В. Кулікова, В.І. Ляшенко, А.А. Мазаракі, Ф. Малерба, Дж. Мур, В.Г. Панченко, І.Ю. Підоричева, М.О. Солдак, В.П. Романов, А.Ю. Яковлева, Р.С. Яремчук. Технологічні тренди й індустрії майбутнього досліджено у працях К. Келлі, А. Росса. Вплив цифрової економіки та трансформацію бізнесу вивчали В.Г. Андрєєва, П.Л. Гринько, С.В. Коляденко, О.С. Вишневський, Р. Хікс та ін.

Мета статті полягає у розробленні практичних рекомендацій щодо управління інноваційним розвитком підприємств в умовах цифровізації шляхом розкриття функцій управління.

Виклад основного матеріалу. Науковці сучасності трактують інноваційний розвиток як «сформовану траєкторію, за якою покращуються якісні та кількісні параметри діяльності організацій, забезпечується зміцнення їхніх конкурентних позицій на ринку, що досягаються через інноватизацію, світовий масштаб котрої зумовлений становленням інформаційно-комунікаційної парадигми розвитку цифрової економіки»; «комплексний соціально-економічний розвиток держави через призму інтелектуалізації капіталу, глобалізацію економічних процесів, становлення знаннєвого суспільства, здобутків НТП із використанням таких механізмів, як хмарні технології, великі бази даних, новітні комп'ютерні технології» [1, с. 83]; «безперервний процес якісних змін цільового характеру, пов'язаних 3 інноваціями, які впроваджуються, відповідно до стратегії розвитку підприємства, за рахунок ефективного використання усіх наявних, у т. ч. інтелектуальних, ресурсів, як власних, так і залучених, і характеризується прогресивною зміною якісного стану усіх сфер діяльності підприємства і визначається його здатністю створювати нові компетенціï, які в теорії стратегічного управління розглядаються як динамічні здатності» [3, с. 87].

Таким чином, управління інноваційним розвитком $\epsilon$ безперервним складним процесом якісних змін на підприємстві на основі інновацій та реалізації функцій управління. Природно, керівники підприємств для досягнення цілей здійснюють усі функції управління: планування, організацію, мотивацію і контроль.

I. Планування. Прогресивні власники та керівники підприємств, вибудовуючи візію та стратегію розвитку бізнесу, надають перевагу саме інноваційному шляху розвитку перед інтенсивним та екстенсивним шляхами. Відповідно до їх концепції розвитку, метою ведення бізнесу є збільшення доходів. Такі керівники вибирають ситуаційний підхід до управління, який добре себе зарекомендував у всьому світі, на противагу адміністративному чи системному. На їхніх підприємствах частка працівників розумової праці перевищує частку працівників фізичної праці або ж постійно ведеться відповідна організаційна робота у напрямі зростання mental labor. Особливістю слідування інноваційному шляху розвитку $є$ наштовхування на постійні зміни i достатньо різку диференціацію запитів споживачів, що, безсумнівно, спонукає до постійного пошуку нових ідей. Окрім того, інноваційний шлях розвитку передбачає змішаний тип ринку покупця і продавця. Хоча інноваційні товари і послуги створюються для того, щоб «вгамувати біль», розв'язати нагальні проблеми споживача, все ж «нав'язує» їх виробник та про- давець. За інноваційного шляху розвитку переважають дрібносерійний і одиничний типи виробництва, нецінова конкуренція, охоплення вибіркових сегментів та ніш ринку, перевищення витрат на збут над витратами на виробництво.

Залучення підприємств у систему стратегічного управління інноваційним розвитком створює низку конкурентних переваг: розширення ринку (за маркетингово-збутових інновацій), зменшення витрат (за антикризових інновацій), вихід на зовнішні ринки (за організаційно-управлінських інновацій), зростання доходів (за продуктових інновацій).

До маркетингових (marketing-mix-related type innovations) i збутових інновацій можна віднести дистриб'юторну політику, ребрендинг торгової марки, іміджевість тощо. До організаційно-управлінських інновацій - упровадження системи менеджменту якості, до антикризових - створення окремих центрів компетенцій з інновацій та цифрових технологій, загальнокорпоративних центрів інновацій чи центру інновацій ритейлу (або для початку відділів маркетингу, логістики, R\&D).

На деяких великих високотехнологічних підприємствах діє так звана «технологічна пісочниця» - майданчик для тестування гіпотез, проведення пілотів зі стартапами й упровадження інноваційних рішень; сервіс стратегічної аналітики, який готує аналітичні матеріали з інноваційних рішень для бізнес- та ІТ-підрозділів; аналітичні (інноваційні) центри (навіть декілька), що займаються інноваційним розвитком підприємств, тощо [4]. Основною метою створення інноваційного центру (або його модифікацій) є приведення інновацій до єдиного стандарту та розповсюдження їх серед усіх відділів підприємства.

Сучасні керівники все більше акцентують увагу на Open Innovation. Практика відкритих інновацій (або створення корпоративного бізнес-інкубатора всередині корпоративного офісу) заслуговує на особливу увагу, оскільки може бути застосована в різних умовах. Наприклад, підприємство може збирати ідеї в мережі Інтернет, пропонуючи за них винагороду, або стати учасником хакатону, отримавши рішення профільних завдань, і т. ін.

II. Організація. Реалії сьогодення такі, що, як i раніше, більшість підприємств форсує інновації заради виконання вимог законів та регуляторів або ж заради підвищення операційної ефективності чи піару. Частка підприємств, які займаються інноваціями заради виходу на нові ринки і випуску нових продуктів та мають посади директора із цифрових технологій або керівників програм цифровізації, або ж підрозділи, які б займалися роботою з інноваціями та НДДКР, не перевищує 5\% (дані однієї з найбільших аудиторських компаній та мереж, що надають професійні послуги, KPMG) [4].

Відзначимо, що посади менеджерів 3 інновацій можуть називатися по-різному: директор з інновацій, із цифрових продуктів, із нового бізнесу або технологій. Звернувшись до офіційної сторінки відомого українського сайту з пошуку роботи Work.ua, бачимо, що станом на 01.04.2021 на сайті була розміщена усього одна подібна вакансія - «менеджер із продажу, розвитку інновацій (східна частина України)» [6]. 
Фахівчиня і практик Л. Голубкова виокремлює три типи інноваційних менеджерів:

1) ІТ-фахівці, люди з інженерною освітою і досвідом;

2) фінансисти й юристи, які керують корпоративними венчурними фондами;

3) управлінці, котрі розуміються на технологіях і менеджменті (посади віцепрезидентів з інновацій) [4].

До сучасних інструментів організаційного розвитку підприємств також відносять крос-функціональну взаємодію співробітників, гнучкі методології праці. Основні проблеми, з якими стикаються управлінці, відсутність культури інновацій, недостатня підтримка топ-менеджменту та співробітників усередині компанії, відсутність загальної мети, недостатність ресурсів для ведення інноваційної діяльності, втрата контролю над організацією процесів, критичне відношення 3 боку партнерів, недостатність загального розуміння, що саме являє собою інновація, відсутність співпраці та обміну інформацією між командами розробників та іншими підрозділами підприємства, недостатність творчих знань, конкурентної розвідки і порівняльного аналізу технологій, відсутність системи мотивації та винагороди (дані KPMG) [5].

III. Мотивація. Мотиваційні установки професійного розвитку залежать від багатьох причин, основною з яких $\epsilon$ вибір підходу до мотивації співробітників. Науковиця С.А. Бондаренко порівняла традиційні та інноваційні підходи до мотивації персоналу підприємств.

Так, за традиційного підходу не передбачається наявність прямого зв'язку мотивації персоналу підприємства 3 реалізацією його цілей. Співробітники не задіяні у формуванні й управлінні корпоративною структурою підприємства. Мотиватором для працівників є заробітна плата, зростання і розмір якої не залежать від результативності й ефективності. Результатами роботи підприємства прийнято вважати суму результатів роботи кожного співробітника. Для всіх співробітників можлива тільки «вертикальна» кар'єра. Передбачається повне або часткове управління і прийняття управлінських рішень керівником підприємства або керівниками підрозділів.

Відповідно до інноваційного підходу, congruity формування системи цільової мотивації, відкритої системи оплати праці, прив'язки соціального пакету до індивідуальних показників результативності й ефективності. Зростає роль командної роботи, під час якої працівники залучені до переговорів, розробок, досліджень і процесу прийняття управлінських рішень. Окрім «вертикальної кар'єри» знизу вверх, має місце «горизонтальна» («матрична») кар'єра. Передбачається навчання протягом усього життя, формування ідей та поглядів creating shared values (CSV) [3, с. 745].

Вітчизняні підприємства тільки-но почали розвивати корпоративну соціальну відповідальність: робити корисні продукти і послуги, жертвувати кошти вразливим верствам населення, займатися доброчинністю в рамках бюджету, тут же опинилися зануреними у створення спільної цінності - створення робочих місць, утворення інноваційних, економічних та соціальних механізмів, інтегрування суспільної цінності у бізнес-модель. При цьому сама соціальна цінність впливає на формування бюджету підприємства, а не навпаки. Учені, які досліджують питання соціаль- ного підприємництва, вважають, що сьогодні єдиною топ-корпорацією, яку можна назвати інноваційною у питаннях CSV, є Tesla [7].

За результатами дослідження щодо впровадження інновацій на підприємствах, проведеного консалтинговою компанією KPMG, виявлено, що більшість підприємств не має окремих систем фінансової і нефінансової мотивації інноваційної діяльності: винагороди визначаються за формальними ознаками і не зіставляються 3 ефектом від упровадження інновацій, тоді як нефінансова мотивація застосовується епізодично.

Близько у 10\% респондентів винагорода залежить від реального ефекту від упровадження інновацій, на стількох же система мотивації охоплює всіх учасників інноваційної діяльності [4].

IV. Контроль. За даними проведеного аналітичного дослідження KPMG, сьогодні традиційна система управління й контролю інноваційного розвитку на підприємствах не в змозі задовольняти умови ринку і спонукати бізнес до постійного генерування ідей. Більшість підприємств за допомогою інновацій змушені захищати поточне становище на ринку або ж «форсують інновації заради виконання вимог законів та регуляторів ... заради підвищення операційної ефективності» і навіть заради піару. Незначна частка підприємств займається інноваціями для виходу на нові ринки і випуску нових товарів і послуг [4]. На наше переконання, контролювати інноваційну діяльність на конкретному підприємстві має менеджер (управлінець) 3 інновацій, який повинен бути висококласним аналітиком, що зможе планувати, організовувати, надихати та контролювати створення ідей та їх конверсію в успішні проєкти задля підвищення економічної ефективності поточних процесів підприємства, поліпшення клієнтського досвіду та масштабованості.

Доцільним буде проведення опитування і тестування на підприємстві та подальше опрацювання відповідей на питання:

- яка мета, місія, візія та корпоративна стратегія підприємства;

- скільки нині ідей є на підприємстві;

- наявність «внутрішніх стартапів» із ризиковими ідеями;

- чи існує альтернативна модель отримання прибутку;

- чи є цифрова стратегія на підприємстві;

- які цілі та вимоги до IT-архітектури підприємства;

- рівень цифрової грамотності співробітників підприємства;

- яка користь для кожного стейкхолдера від діяльності підприємства.

Державне регулювання та підтримка інноваційного розвитку підприємництва здійснюються у правовому, політичному, економічному, субсидіарному та інших аспектах. Оскільки підприємництво за своєю суттю є інноваційним, розглянемо його остов - мале та середнє підприємництво як об'єкти управління. Державна підтримка розвитку малого і середнього підприємництва здійснюється засобами надання освітніх, навчальних та консалтингових послуг, зокрема: 1) запровадження навчання основам підприємництва; 2) здійснення перепідготовки і підвищення кваліфікації у сфері підприємництва; 3) проведення навчальних семінарів, тренінгів, форумів, круглих столів та конференцій; 4) фінансу- 
вання бізнес-проєктів. За даними Міністерства розвитку економіки, торгівлі та сільського господарства, регіонами-лідерами за першим показником є Львівська область, за другим - Черкаська, третім - Донецька й останнім - Львівська область [8].

Варто зауважити, що інфраструктурна підтримка малого і середнього підприємництва по регіонах непропорційна (у 2019 р. кількість громадських об’єднань підприємців у Полтавській області становила 2708 од., натомість у Волинській області - 28, Тернопільській - 30, Одеській та Луганській - по 38 од.; найбільша кількість інформаційно-консультативних установ, природно, була у Києві (658 од.), Полтавській області (615 од.), тоді як у Херсонській та Волинській області - по 1, в Одеській - жодної). Природним $\epsilon$ нагромадження бізнес-центрів, техно- та індустріальних парків у промислових регіонах. Однак невиправданим, на нашу думку, є повна відсутність бізнес-інкубаторів у Вінницькій, Кіровоградській, Луганській, Одеській та Чернігівській областях, відсутність лізингових центрів, інвестиційних та інноваційних фондів у Волинській та Чернігівській областях [8].

У всіх регіонах України функціонують інституції підтримки малого та середнього підприємництва. Наприклад, у Дніпропетровській області - ГО «Дніпропетровський координаційно-експертний центр 3 питань регуляторної політики» (з 2005 р.), ГО «Асоціація «Правозахист» (з 2006 р.), ГО «Український захист» (з 2011 р.), ГО «Дніпропетровська обласна організація роботодавців експертних та інспекційних організацій» (3 2015 р.), ГО «Агенція економічного та соціального розвитку м. Тернівка Дніпропетровської області» (3 2012 р.), КП Компанія «Арлен» (з 2000 р.), ГС «Міжнародна бізнес-асоціація» (з 2015 р.), ГО «Нікопольська агенція регіонального розвитку» (з 2015 р.). У Харківській області діє благодійна організація «IDP Business Space - соціальний бізнес-простір», що включає коворкінг, івент-зону для заходів, презентацій, зону-навчання для майстер-класів, тренінгів, зону для проведення переговорів і продакшн-зону; ГО «Добра воля» і Бізнес-інкубатор Харківського національного університету міського господарства ім. О.М. Бекетова, що підтримують новостворені підприємства; Об'єднання підприємців «Слобожанщина», Асоціація приватних роботодавців і деякі інші [9].

Серед основних напрямів діяльності даних інституцій - інформаційна, аналітична, консультаційна, юридична та комунікаційна підтримка, навчальні програми та тренінги, захист прав і представництво інтересів.

Висновки. Таким чином, логічним $\epsilon$ висновок про те, що сьогодні всі функції управління пронизані цифровізацією. Через це прогресивним власникам та керівникам підприємств слід вибрати інноваційний шлях розвитку; до організаційної структури підприємств включити центр інновацій (підрозділ НДДКР, загальнокорпоративний центр інновацій, сервісний центр стратегічної аналітики або центр технологічної експертизи і розвитку); утворити систему фінансової і нефінансової мотивації інноваційної діяльності; налагодити партнерську взаємодію з науковими організаціями, технологічними компаніями та вищими навчальним закладами.

\section{Список використаних джерел:}

1. Гринько П.Л. Методологія управління інноваційним розвитком бізнесу в умовах цифрової економіки : дис. ... докт. екон. наук : 08.00.04. Харків, 2020. 522 с.

2. Ляшенко В.І., Вишневський О.С. Цифрова модернізація економіки України як можливість проривного розвитку : монографія. Київ : НАН України, Ін-т економіки промисловості, 2018. 252 с.

3. Бондаренко С.А. Теоретико-методологічні засади системного забезпечення стійкого інноваційного розвитку виноробних підприємств : дис. ... докт. екон. наук : 08.00.04. Одеса, 2018. 755 с.

4. Подцероб М., Петрова Ю. Как крупнейшие компании внедряют инновации и что неправильно в оценке инновационных проектов и системе мотивации. URL: https://www.vedomosti.ru/management/articles/2020/09/24/841148-krupneishie-kompanii (дата звернення: 20.03.2021).

5. Корпоративные инновации KPMG. URL: https://assets.kpmg/content/dam/kpmg/ru/pdf/2017/11/ru-ru-corporate-innovations.pdf (дата звернення: 24.03.2021).

6. Сторінка сайту пошуку роботи Work.ua. URL: https://www.work.ua/ru/jobs/4088077/ (дата звернення: 22.03.2021).

7. Корнецький А., Язвінська М., Конопкін В. Соціальна економіка: де тут гроші. VoxUkraine. URL: https://voxukraine.org/uk/ sotsialna-ekonomika-de-tut-groshi/ (дата звернення: 22.03.2021).

8. Окремі показники підтримки та розвитку малого і середнього підприємництва станом на 01.01 .2019$. URL: https://www.me.gov.ua/Documents/Detail?lang=uk-UA\&id=0ced3c9f-a057-4852-9072-151dd387356a\&title=Institutsii-SchoZ abezpechuiutPidtrimkuPidprimnitstva (дата звернення: 20.03.2021).

9. Каталог інституцій підтримки малого та середнього підприємництва. URL: http:/www.lev.org.ua/ua/institutions.html? region $=2 \&$ type $=0 \&$ direction $=0$ (дата звернення: 22.03.2021).

10. Стратегическая гибкость / Г. Хэмел и др. Санкт-Петербург : Питер, 2005. 384 с.

11. Вишневський О.С. Цифрові платформи як ядро цифровізації економіки. Цифрова економіка : зб. мат. Національної наук.-метод. конф., м. Київ, 4-5 жовтня 2018 р. Київ : КНЕУ, 2018. 407 с.

\section{References:}

1. Hrynko P. L. (2020). Metodolohiia upravlinnia innovatsiinym rozvytkom biznesu v umovakh tsyfrovoi ekonomiky [Methodology for managing innovative business development in a digital economy]. (PHD Thesis), Kharkiv: Kharkiv State University of Food and Trade.

2. Liashenko V. I., Vyshnevskyi O. S. (2018). Tsyfrova modernizatsiia ekonomiky Ukrainy yak mozhlyvist proryvnoho rozvytku [Digital modernization of Ukraine's economy as an opportunity for breakthrough development]. Kyiv: NAS of Ukraine, Institute of Industrial Economics.

3. Bondarenko S. A. (2018). Teoretyko-metodolohichni zasady systemnoho zabezpechennia stiikoho innovatsiinoho rozvytku vynorobnykh pidpryiemstv [Theoretical and methodological principles of system support for sustainable innovative development of wineries]. (PhD Thesis), Odesa: Institute of Market Problems and Economic and Ecological Research of the National Academy of Sciences of Ukraine. 
4. Podtserob M., Petrova Yu. Kak krupneyshie kompanii vnedryayut innovatsii. I chto nepravilno v otsenke innovatsionnyih proektov i sisteme motivatsii [How the largest companies innovate. And what is wrong in the assessment of innovative projects and the motivation system]. Available at: https://www.vedomosti.ru/management/articles/2020/09/24/841148-krupneishie-kompanii (accessed 20 March 2021).

5. Korporativnye innovaczii KPMG (2021). Available at: https://assets.kpmg/content/dam/kpmg/ru/pdf/2017/11/ru-ru-corporate-innovations.pdf (accessed 24 March 2021).

6. Storinka saitu poshuku roboty Work.ua (2021). Available at: https://www.work.ua/ru/jobs/4088077/ (accessed 22 March 2021).

7. Kornetskyi A., Yazvinska M., Konopkin V. (2021) Sotsialna ekonomika: de tut hroshi [Social economy: where is the money]. Vox Ukraine. Available at: https://voxukraine.org/uk/sotsialna-ekonomika-de-tut-groshi/ (accessed 22 March 2021).

8. Okremi pokaznyky pidtrymky ta rozvytku maloho i serednoho pidpryiemnytstva [Some indicators of support and development of small and medium enterprises] (2019). Available at: https://www.me.gov.ua/Documents/Detail?lang=uk-UA\&id=0ced3c9f-a057-4852-9072-151dd387356a\&title=Institutsii-SchoZabezpechuiutPidtrimkuPidprimnitstva (accessed 20 March 2021).

9. Kataloh instytutsii pidtrymky maloho ta serednoho pidpryiemnytstva [Catalog of small and medium business support institutions]. Available at: http://www.lev.org.ua/ua/institutions.html?region=2\&type=0\&direction=0 (accessed 22 March 2021).

10. Hemel G., Prahalad K., Tomas G., Nil O. (2005). Strategicheskaya gibkost. Saint Petersburg: Piter. (in Russian)

11. Vyshnevskyi O. S. (2018). Tsyfrovi platformy yak yadro tsyfrovizatsii ekonomiky [Digital platforms as the core of the digitalization of the economy]. Tsyfrova ekonomika: zb. mat. Natsionalnoi nauk.-metod. konf. Kyiv: KNEU.

Horiashchenko Yuliia

University of Customs and Finance

\section{MANAGEMENT OF INNOVATIVE DEVELOPMENT OF ENTERPRISES IN THE CONDITIONS OF DIGITALIZATION}

The purpose of the study is to develop practical recommendations for the management of innovative development of enterprises by disclosing management functions in the context of digitalization. The concept of innovation development management is defined as a continuous complex process of qualitative changes in the enterprise on the basis of innovation and implementation of all management functions. The category "philosophy of innovative entrepreneurship» is proposed as a process of finding answers to major business questions through reasoning, intelligence, knowledge, wisdom in order to guide the main actors of innovative development in building the innovation ecosystem of the state and the world. The need to involve enterprises in the system of strategic management of innovative development to create competitive advantages, such as market expansion, cost optimization, access to foreign markets, revenue growth, etc. is emphasized. It is emphasized that the management of innovative development of the enterprise is based on the implementation of innovative practices for the development of creativity, flexibility, openness to external influences. Emphasis is placed on the need to create separate centers of competence in innovation and digital technologies or corporate innovation centers (retail innovation center), as well as to involve innovation managers in the staff. The advantage of innovative approaches to staff motivation over traditional ones is proved. It is proposed to conduct a survey to determine the status and level of professional motivation of employees in order to support innovative development. Emphasis is placed on the growth of a special type of innovation among managers - managers who understand technology and management (positions of vice presidents for innovation), as well as IT specialists, financiers and lawyers who manage corporate venture funds. Examples of marketing and sales, anti-crisis, organizational and managerial, product innovations are given. The positions of the state on the regulation and support of innovative development of entrepreneurship in the regions are outlined. Infrastructural support of small and medium business in the regions of Ukraine is considered.

Key words: innovative development of enterprises, digitalization, management, philosophy of innovative entrepreneurship, business, organization.

JEL classification: M21, O14, O31 